\title{
Drivers of Savings Account Ownership Status: A Cross-Sectional Analysis from Ghana
}

\author{
Augustine Kwadwo Yeboah \\ Department of Banking and Finance, Ghana Baptist University College, Kumasi, Ghana \\ yeboagus@yahoo.com
}

\begin{abstract}
In view of the evidence that poor savings can inhibit investment decision by borrowers of surplus funds, and that countries with well-established and efficiently utilised financial services have considerably less poverty, the study examines factors influence saving account ownership in Ghana using econometric approach. We used empirical evidence with data sourced from informal market traders in selected major market centres in Ghana. Using probit regression analysis, the results suggest that financial educations, number of income-generating ventures engaged in by the market trader are major predictors of savings account ownership status. Other predictors include demographic characteristics such as gender, age, marital status and number of dependents. It is, therefore, recommended that banks and financial institutions should intensify financial education strategies to boost savings mobilization. Government's policy intervention should be directed towards informal sector enterprise development to the crowd in revenue in order to motivate decisions to save. Also, the National Board for Small Scale and informal Businesses in Ghana should intensify education on how to sustain diverse income generation ventures to fetch income from multiple sources in order to encourage behavioural intentions to save.
\end{abstract}

Keywords: Savings account, cross-sectional analysis, probit regression analysis, informal market traders, Ghana

\section{Introduction}

Well managed financial services play an enormous role in shaping the economic fortunes of nations. It has, therefore, been argued that countries with well-established and efficiently utilised financial services have considerably less poverty (Afoakwah, Annim, \& Peprah, 2015). It has long been established that poor households in developing countries may benefit immensely from saving mobilization, particularly improved access to credit, the benefit of profitable investment prospects, consumption smoothing and insurance protection against emergencies (Zeller, 1999). In poor developing countries the mainstay of economic activities is predominantly the informal sector as the sector's contribution to growth prospects cannot be discounted (Musah, Bagah, \& Wulifan, 2015). This notwithstanding, only $41 \%$ of the economically active adult population in poor developing countries have a bank account (Goldberg, 2014). Economically, poor saving habits can inhibit investment decision by borrowers of funds. The situation becomes more critical when investors desire to borrow is relatively large. The argument, therefore, is that by aggregating a large number of small saving deposits, financial intermediaries will be in a position to satisfy demands for large loans (Incoom, 2009). Again, promoting saving mobilization is important to enterprise development due to the availability of adequate capital to overcome credit constraints (Abebe, Yukichi, \& Biruk, 2018). In spite of these inherent benefits connected to savings, in developing countries widespread poverty has precluded many to save (Karlan \& Zinman, 2018).

These inconclusive revelations suggest that the potential inhibition factors which have stifled the efforts to save need thorough empirical investigation. Modigliani (1986) raised fundamental argument concerning the necessity of savings through the 'life cycle hypothesis'; suggesting that individuals try to smooth consumption by saving during the period of earning and draw down savings during retirement. The motivation to provide for anticipated future expenses, precautionary, enterprise and bequest motives are perceived to have characterised decisions to save. For many, the practical reasons why people save are to prepare for a possible financial crisis caused by illness, divorce, job loss and accident (Olson \& DeFrain, 2000). Evidence, however, suggests that the poor benefits greatly from financial inclusion through savings yet, the proportion of households with a formal savings account is very low (Ackah \& Asiamah, 2014). It has been argued that the rigidity that characterizes saving decision is partly attributed to non-removal of artificially low-interest rate on savings as nations advance towards financial liberalization (Todaro \& Smith, 2009). Perhaps the attribution of low savings to interest rate and saving nexus is underpinned by the argument that higher interest rate on savings should crowd in more domestic savings and facilitate domestic fund mobilization by allocating more loanable funds. 
Recent developments suggest that the financial market in Ghana is highly fragmented with only 5 to 6 percent of the population accessing services from the commercial banks (Basu et al., 2004) and 16 percent have access to an account with a financial intermediary (World, 2008). The ultimate decision to save by economic agents therefore, can be likened to inter-temporal resource allocation. For instance, it is argued that the decision to save encourages households' alternative consumption smoothing ability to adopt less current consumption for future consumption. In line with this argument, Gravelle and Rees (2004) submit that savings smooth out unanticipated vagaries in income flow and other economic shocks faced by economic agents. In spite of the efforts to ensure a sound financial system which encourages savings, it is perceived that barriers to savings exist for the poor thus, discouraging many informal business owners to save. The situation, particularly in Ghana is serious; since savings habits among the informal sector have been found to be depressing leading to wanton misery among the informal sector workers (Addai et al., 2017).

The relevance of this study is undoubtedly timely in the wake of the current circumstance of poorly managed income generation ventures by the informal sector workers, particularly informal market traders in Ghana. Again, the need for financial resource mobilization to resource deficit financial units with funds to invest and expand income generation ventures calls for a thorough investigation into underlying factors governing savings account ownership in Ghana. In spite of the growing evidence that savings and investment accumulated domestically facilitates the means of resourcing and aiding the growth of economic projects to fuel the engine of economic prosperity, poor savings habit has stifled the efforts to expand informal sector economic ventures in Ghana. Though, a number of studies have investigated savings habits the critical question of what influence savings account ownership status among individuals engaged in informal sector activities is not clear. Consequently, this study sought to examine social, economic and demographic factors influencing behavioural intentions to operate savings account. The rest of the paper is organized as follows: Section two is devoted to literature review. Section three covers the methodology and model specification, Section four deals with results and discussion and the final section presents conclusion and recommendations.

\section{Literature Review}

Theoretical Perspectives of Saving Behaviour: Although, the theoretical and empirical literature about drivers of savings has grown, evidence of the inclination to save has remained rare among informal sector workers in Ghana, particularly informal commercial market traders. To save is to set aside a certain amount of income for future use. The economic reason to save therefore is grounded on consumption smoothing due to anticipated future expenses. Thus, the ability to save is predominantly dependent on income available to households, firms and corporate entities. Theoretically, financing real consumption is dependent on current real disposable income (Keynes, 1936). This theoretical proposition by Keynes was anchored to the strong assumption that the marginal propensity to consume increases as income increases. This presupposes that with consumption and savings being dependent on current income, an increase in income could increase the capacity to save. This suggests that any economic opportunity that can increase income gives the individual the motivation to commit to savings habit.

Life-Cycle Theory of Saving Behavior: According to Ando and Modigliani (1963), one of the most significant motives for putting money aside is underpinned by the fundamental requirement to cater for future retirement. This assertion implies that young individuals in gainful employment start with low income and possibly low savings rates. As income rises in their middle ages so will their savings rise. According to the theory, retirement is associated with a fall in income and possibly a fall in consumption. This naturally makes current savings commitments important to smooth future consumption needs. In a clearer view, the exposition advanced by Keynes (1936) connecting savings, consumption and income stands to buttress the point underpinning the life-cycle theory. The idea about the causal link between income growth and saving growth is well established in the sense that with increasing income, the young will save more than the old so that income growth causes positive savings.

The Permanent Income Hypothesis of Saving Behaviour: The permanent income hypothesis provides a flexible framework for the study of consumption and savings. Theoretically, consumption is perceived to play a primary role in human life whereas saving acts in a passive residual character (Vosen, 2012). According to 
Friedman (1957), Permanent Income Hypothesis (PIH) assumes that households consume a fraction of their permanent income and flexibly adjust savings to transitory income flows. Thus, it was grounded on the assumption that consumption was a continuous function of income. The strongest conviction underpinning this hypothesis; therefore, is that temporary income has no impact on permanent consumption behaviour of economic agents. Under this assertion, it was hypothesised that human capital, wealth, age and income distribution may prove as strong predictors of savings and consumption behaviour.

Empirical Literature Review: Drivers of the decision to save have remained varied and complex in nature. Kalan and Zinman (2018) examined price and control elasticity of demand for savings using bank randomization of potential clients and found minimal demand sensitivity and thus, price elasticity of saving is not significantly different from zero. The study approach is plausible; however examining saving account sensitivity could have been concurrently investigated with important socio-economic covariates driving saving account ownership among potential clients of banks. Rehman, Faridi and Bashir (2012) examined household savings behaviour in Pakistan with field data involving 293 respondents and found that spousal participation dependency rate, income and landholding drive saving behaviour. On the other hand, education, children education expenditure, family size and marital status significantly reduce savings behaviours among households. However, counterintuitive relationship between education and saving needs further empirical proof. An empirical study by Amu and Amu (2012) on saving behaviour of rural households in Ho Municipality of Volta Region of Ghana, the study found a low level of knowledge about savings among household heads; also, personal social and organizational limitations stifle the efforts of households to save. The findings of the study sound appealing; however, limiting the study of households' saving behaviour to rural areas can affect the generalizations of an empirical study of this nature.

Associating to this is a study by Arent (2012) which empirically investigated expectation and saving behaviour and found that a higher unemployment expectation strongly decreases savings. The study, however, failed to establish a clear relationship between future income expectations; a strong, compelling factor in savings decisions and savings behaviours among households. Dupas and Robinson (2013) examined saving constraints and microenterprise development in Kenya. Using a sample of 392 individuals, the study found that greater proportion of micro-entrepreneurs in rural Kenya face major savings constraints notably awareness about the need to save, social pressure to share limited resources and inaccessibility to banking services. On the basis of these findings, the study suggests the extension of banking services to the doorsteps of potential savers to increase the number of individuals who want to save. This suggestion sounds quite appealing, however, the study failed to emphasize possible limitation created by poor income generation and environmental factors that inhibit the motivation to save out of low-incomes. In a related study in Ghana, Osei-Assibey (2013) investigated the effect of sources of start-up finance on micro and small enterprises productivity growth. Using non-farm household enterprise survey data, the study found debt finance as a major predictor of productivity growth; whereas finance from donations and charity impact negatively on firm productivity growth. The findings imply that availability and accessibility to surplus funds as a source of borrowing could have an enormous impact on business prospects of small scale and informal enterprises.

However, the emphasis on other important socio-economic governing factors and how they impact on micro and small business productivity growth did not feature prominently in the study. As part of the efforts to ascertain patronage of banking services, Yee-Kwong (1996) in a survey of college students in Hong Kong examined banking services for young intellectuals and found out that savings account constituted the most common type of bank account owned by college students. Though the study sought to emphasize awareness and understanding as factors which inform prospective savers; it did not clearly examine those factors to support the revelation of significant saving behaviour by prospective savers. Related to this is a study by Owusu-Bempah, Bennet, Amoako and Frimpong (2013), which examined the importance of the informal sector of Ghana to savings and loan companies. The study found the informal sector paramount in contributing to the development of savings and loan companies. The implication of contributing to the growth of savings and loan companies via saving mobilization made possible through savings account ownership and other related factors were not dealt with in the study. In an empirical study by Addai, Adjei and Boadi (2017), the study investigated savings habit among individuals in the informal sector. Using 120 sampled respondents the probit regression analysis revealed that the main inhibiting factor affecting motivation to save was low-income among individuals in the informal economy. 
The study thus, recommends intervention via education to enhance income earning capacities of informal sector operators. However, the need to adopt a comprehensive approach to tackle low-income levels may go beyond the bounds of education. So other socio-economic factors could have been given prominence in the study. In another close study, Abdul Mumin, Razak and Domanban (2013) examined household heads decision to save in the Bole District of Ghana. Using data from 120 household heads, the logistics regression analysis revealed educational status, the value of assets shock to household head and commitment to financial institutions as major predictors of saving behaviour of households. Though the revelation from the study sounds pleasing; one is concerned about the specific measurement criteria used for some of the variables such as shock to the household head and commitment to financial institutions. Failure to address these has downside implications for the study. Karlan, Ratan and Zinman (2014) on review of savings by the poor and for the poor found development of efficient innovations and interventions that underpin awareness and understanding of saving decisions of households and individuals as surest routes to savings motivation by the poor. The study further suggests a focus on potential barriers to savings. The background information provided by the study sounds appropriate; however specific focus variables that connect and govern savings decisions are not clear in the analysis of the study.

In a related empirical study, Dziwornu and Anagba (2014) examined factors influencing saving decision among small business owners in Ghana. Using data from 304 small business owners, the results revealed that on the average, the respondents save GH $\$ 16.00$ daily and interest on savings, knowledge about savings, available saving schemes to join and motive about future purchase were the driving forces of the decision to save. The study findings are quite revealing; however, socio-economic and other demographic factors that shape perception and decision to save were not given prominence in the study. Tandoh and Tandoh (2015) investigated the dynamics of a savings culture in Ghana and found high savings culture among respondents but, respondents preferred to save more for the future rather than for current consumption. Though the study reveals savings preference of respondents the practical reason for not opting for current savings but rather saving for the future was not clear. Schaner (2016) used field experiment data to examine how temporary incentives to save affect long-term economic outcomes in rural Kenya. The study found that the absolute value of savings incentive does not matter the delivery mode but motivating individuals to own bank account impacts strongly on enterprise development and income. The study's outcome is important, particularly it has implications for poor emerging economies with low saving mobilization. However, the need to examine fundamental social and economic factors motivating saving among the poor is paramount, particularly among households engaged in informal sector activities.

\section{Data Source, Sampling Procedure and Method of Analysis}

To ensure reliable survey results, we sampled economically active informal market traders from six selected major market centres from the north, middle and coastal zones of Ghana. In selecting the markets, we employed a multi-stage cluster sampling technique given consideration to size, development and vibrancy of market centres across the country. Thus, the study areas were delineated into zones involving a cluster of market centres. In each zone, we identified four (4) main major clusters of market centres; then two (2) most vibrant market centres were selected from each cluster. In the northern zone, for instance, we selected markets to include Bolgatanga old market and Tamale central market. Others were Sunyani main market and Kumasi central market in the middle zone; then Takoradi market circle and Kaneshie market complex, all in the coastal zone of Ghana. The respondents were then selected by convenience from the market centres through face-to-face interview due to easy accessibility of the market participants.

The data was obtained from 612 informal market sellers who conduct daily trading activities in the selected markets centres. The survey data contains information on features such as savings account ownership status, the number of dependents, number of income-generating ventures owned by the respondent as at the time of the study, financial education and number of years of market trading experience. We also collected information on respondent's basic demographic characteristics such as gender, age and marital status. The basis of this method is grounded on the neoclassical economic theory of choice, which assumes that economic agents such as individual decision makers are rational beings who respond to certain broad predictors of human behaviour; namely social and economic specific factors, which may act as opportunities or constraints. 
Therefore, soliciting for socio-economic specific data from economic agents demands a systematic approach in order to ascertain the level of accuracy of the data gathering process.

Theoretically, an individual's utility (satisfaction) is hypothesised to be a function of consumption and saving (Addai et al., 2017). Thus, the life-cycle and the permanent income hypotheses have emphasized long-term consumption motives in support of savings decision. Both theories have been emphasised in this study. In view of this, the question of whether empirical support can be offered through field survey data underpins the discourse of this study.

The Model and Estimation Technique: Employing a probit regression model, we specify a binary outcome model for a respondent's ownership of savings account or otherwise. A binary probit model relates the probability of the event occurring to the probability of the event not occurring. This follows a specification of a simple binary probit model as:

$y_{i}^{*}=\boldsymbol{x}_{\boldsymbol{i}} \beta+\varepsilon$

Where, $y$ takes the value one ( $y=1$ ), if a commercial market trader owns and operates saving account with a bank and zero $(y=0)$ otherwise. Thus, the dichotomous dependent variable $y$ is not directly observed. If the observed binary outcome variable $(Y)$ is an expression of whether or not the person owns and operates savings account or not, then, for such a binary outcome, the underlying latent propensity or desire to save is given by $y^{*}$. Therefore, when a person's desire to save is greater than zero $\left(y^{*}>0\right)$ then a person has a positive decision towards saving account ownership. In this light, the definition of a binary response variable can be expressed as follows:

$Y_{i}=\left\{\begin{array}{l}1 \text { If } y^{*}>0 \\ 0 \text { If } y^{*} \leq 0\end{array}\right.$

Thus, the underlying unobservable latent dichotomous outcome $\left(y^{*}\right)$ defines the generalized form of the probit regression model. Thus, variable $\boldsymbol{y}^{*}$ is an unobserved dichotomous response variable, $\boldsymbol{x}_{\boldsymbol{i}}$ is a vector of explanatory variables, $\boldsymbol{\beta}$ represents parameters to be estimated and $\boldsymbol{\varepsilon}$ is the disturbance term.

Theoretically, when the outcome response variable $Y$ is binary with values 0 and 1 , the specification of the probit equation assumes the following form:

$p=\operatorname{Pr}(Y=0)=K+(1-K) F(x, \beta)$

Where; $\boldsymbol{x}$ a vector of explanatory variables, $\boldsymbol{\beta}$ is a vector of parameter estimates, $p$ is a probability of a response, $K$ is a threshold response rate and $\boldsymbol{F}$ a cumulative distribution function. Following this generalized form, the empirical probit model is specified as:

$p=\operatorname{Pr}\left(S_{-}\right.$accountOwn $\left.=1 \mid x_{i}\right)=\beta_{0}+\beta_{1} X_{1}+\beta_{2} X_{2}+\beta_{3} X_{3}+\beta_{4} X_{4}+\beta_{5} X_{5}+\beta_{6} X_{6}+\beta_{7} X_{7}+\varepsilon_{i}$

Where:

$S \_$account $O w n=$ is savings account ownership status

$X_{1}=$ gender of the respondent

$X_{2}=$ the age of the respondent

$X_{3}=$ Marital status of the respondent

$X_{4}=$ Number of dependents

$X_{5}=$ Number of income generating ventures owned

$X_{6}=$ Financial education

$X_{7}=$ Years of market trading experience

\section{Results and Discussion}

This section of the study discusses the results obtained from the probit regression model. Prior to the discussion of the results, Table 1 presents the definition and measurement of the variable used in the empirical probit regression model and a priori signs. As shown in Table 1, the variable labelled S_accountOwn is a binary response variable, which assumes the value one (1) if the respondent owns a savings account with a bank or any financial institution and zero (0) otherwise. The variable $\operatorname{Gender}\left(\boldsymbol{X}_{1}\right)$ describes whether the respondent is a female or a male. It assumes the value one (1) if the respondent is a female and zero (0) otherwise. Variable $\boldsymbol{A g e}\left(\boldsymbol{X}_{2}\right)$ is a continuous variable, which measures the respondent's age in years. Also, the variable marital status $\left(\boldsymbol{X}_{3}\right)$ describes current marital status of a respondent and it is captured as a categorical variable with categories including single, married, divorced and widowed; with 
widowed used for the analysis as the reference category. Dependents $\left(\boldsymbol{X}_{4}\right)$ measure the number of dependent members under the support the respondent. Again, the variable income generating ventures $\left(\boldsymbol{X}_{5}\right)$ denotes number of income receiving business transactions engaged in by the respondent as at the time of the study.

Further, the variable labelled financial education $\left(\boldsymbol{X}_{\mathbf{6}}\right)$ is a dummy variable which measures whether a market trader has received financial education from financial service providers since the respondent's engagement in the market trading activities or otherwise. It takes the value one (1) if the respondent has financial education from financial service providers and zero (0) otherwise. Finally, as shown in Table 1, the variable captured as years of market experience $\left(\boldsymbol{X}_{7}\right)$ is a measure of number of years that the market trader has engaged in the market trading activities. It is presumed that years of market experience has implication for the respondent overall financial planning and decision, particularly in planning for future uncertainties, and thus, individuals who have sustained their market businesses for some time may opt for savings to solidify business continuity. Hence, an increase in number of years in business is expected to have positive impact on savings account ownership.

Table 1: Definition, Measurement of Variables in the Probit Model and a Priori Signs

\begin{tabular}{|c|c|c|c|}
\hline Variable & Description & Measurement & $\begin{array}{l}\text { a priori } \\
\text { signs }\end{array}$ \\
\hline Gender $\left(X_{1}\right)$ & Gender of the respondent & 1 , if female, and 0 male & $-/+$ \\
\hline Age $\left(X_{2}\right)$ & The age of the respondent & Number of years & - \\
\hline Marital Status $\left(X_{3}\right)$ & Current marital status & a categorical variable & $-/+$ \\
\hline \multicolumn{4}{|l|}{ Single } \\
\hline \multicolumn{4}{|l|}{ Married } \\
\hline \multicolumn{4}{|l|}{ Divorced } \\
\hline Widowed & & & \\
\hline Dependents $\left(X_{4}\right)$ & $\begin{array}{l}\text { Family members who rely on the } \\
\text { respondent for support }\end{array}$ & Number of dependents & - \\
\hline $\begin{array}{l}\text { Income generating } \\
\text { ventures }\left(X_{5}\right)\end{array}$ & $\begin{array}{l}\text { Income generating activities engaged } \\
\text { in by a respondent }\end{array}$ & $\begin{array}{l}\text { Number of income generating } \\
\text { activities }\end{array}$ & + \\
\hline $\begin{array}{l}\text { Financial } \\
\text { education }\left(X_{6}\right)\end{array}$ & $\begin{array}{l}\text { Respondent's engagement in financial } \\
\text { education }\end{array}$ & $\begin{array}{l}1 \text { if the respondent has } \\
\text { received any form of financial } \\
\text { education since engaging in } \\
\text { business, and } 0 \text { otherwise }\end{array}$ & + \\
\hline $\begin{array}{l}\text { Years of market } \\
\text { experience }\left(X_{7}\right)\end{array}$ & $\begin{array}{l}\text { Years that the respondent has been in } \\
\text { market business }\end{array}$ & Number of years & + \\
\hline
\end{tabular}

Source: Field survey data August, 2015

The next section presents the probit regression results shown in Table 2. The section follows with discussion of results, major conclusions and implications drawn from the discussion. On the relationship between gender and savings account ownership, the results in Table 2 show that being female decreases the probability of owning savings account by 0.207 compared to being a male. This revelation is not surprising. In fact, due to male dominating nature of African societies and the role of men in the households of Africa, the desire for men to own savings account far exceeds that of their female counterparts. This presupposes that when the market women are empowered to augment their earnings from their income generating ventures, they can set aside some proportion of income for savings purposes. This confirms a related finding by Afoakwah et al. (2015) Who found that empowerment of women provides assurance of financial security of the household and this will motivate women to save. The effect of age of the market trader has a statistically significant association with savings account ownership decision.

From the estimation, there is a positive relationship between the age of a market trader and savings account ownership status. However, the square of the age as shown in Table 2 is significant but negatively associated with savings account ownership status. This confirms the hypothesised non-linear relationship pointed out in conceptual studies that as individuals grow older, they are more likely to be poor because of inability to engage in economic activities (United Nations Development Programme, (2007). This situation has a strong likelihood of decreasing savings account owned by older market traders (Acheampong \& Wiafe, 2013). On the 
relationship between marital status and savings account ownership, the results from the analysis shown in Table 2 reveal that being a single decrease the probability of individual market trader's ownership of savings account by 0.012 compared to being a widow who has been used as the reference category. This finding sounds plausible in that, being a single put all economic pressure solely on one person, particularly if the individual is the breadwinner of the household. This situation can decrease the desire to open a savings account.

Table 2: Results of Probit Regression of Market Traders' Saving Account Ownership Status

\begin{tabular}{lcccc}
\hline Variable & Coefficient & t-Statistics & $\begin{array}{c}\text { Marginal } \\
\text { Effect }\end{array}$ & P-value \\
\hline Gender $\left(X_{1}\right)$ & -0.023 & $-2.13^{*}$ & -0.207 & 0.063 \\
Age $\left(X_{2}\right)$ & 0.240 & $1.43^{* *}$ & 0.064 & 0.041 \\
Age Squared $\left(\mathrm{X}_{2}\right)$ & -0.022 & $-2.11^{*}$ & -0.005 & 0.054 \\
Marital Status $\left(X_{3}\right)$ : Widowed & - & - & - & - \\
Single & -0.124 & $-1.54^{* *}$ & -0.012 & 0.044 \\
Married & 0.110 & $-1.12^{*}$ & 0.011 & 0.063 \\
Divorced & -0.231 & $-3.62^{*}$ & -0.134 & 0.091 \\
Dependents $\left(X_{4}\right)$ & -0.432 & $-3.42^{* * *}$ & -0.131 & 0.001 \\
Income generating ventures $\left(X_{5}\right)$ & 0.256 & $2.32^{*}$ & 0.023 & 0.073 \\
Financial education $\left(X_{6}\right)$ & 0.124 & $3.30^{* * *}$ & 0.113 & 0.004 \\
Years of market experience $\left(X_{7}\right)$ & 0.022 & 0.32 & 0.211 & 0.143 \\
Constant & -2.134 & $-4.90^{* * *}$ & - & 0.002 \\
Number of Observations (N) & $(612)$ & & & \\
$\mathrm{R}^{2}$ (pseudo) & $(0.1124)$ & & & \\
Hosmer-Lemeshow Gof test $(\mathrm{P}-$ value) & $(0.2113)$ & & & \\
Linktest-_hat Squared (P-value) & $(0.553)$ & & & \\
& & & &
\end{tabular}

Source: Field Survey data August, 2015

NB: **: significant at $1 \%(\mathrm{p}<0.01)$; $^{* *}$ : significant at $5 \%(\mathrm{p}<0.05)$; $^{*}$ : significant at $10 \%(\mathrm{p}<0.10)$

Again, from the results in Table 2, being a married person increases the probability of owning savings account by 0.011 compared to being a widow. This revelation is possible in the sense that married couples can pool their income resources together and from this pool income, the desire to save for future consumption purpose is possible. This confirms pool income hypothesis which asserts that men and women continue to participate in the marital arrangement so long as their utilities within the arrangement exceed the utility level that they could get outside the arrangement (Chen \& Dunn, 1996). Also, the results have found that being a divorcee decreases the probability of owning savings account by a market trader by 0.134 compared to being a widow all things being equal. The basis of every marriage is to support each other not only emotionally but more importantly economically. Thus, divorced individuals have the sole obligation of carrying all family responsibilities if the marriage is no more. This circumstance invariably inhibits the efforts of many divorcees in their efforts to save. Again, the probit analysis showed a negative relationship between a number of dependents and savings account ownership. The coefficient 0.432 and the marginal effect 0.131 for dependents obtained from the analysis suggest that an increase in the number of dependents reduces the probability that a market trader will own a savings account by 0.131 , all things being equal. The negative coefficient suggests that an increase in the number of dependents by one person overburdens the market trader and this makes the individual disinclined to set aside income resources for saving purpose.

This finding confirms the assertion by Dupas and Robinson (2013) that a greater proportion of microentrepreneurs face major savings constraints due to social pressure to share limited resources. Moreover, at five percent significant level, the study reveals a positive relationship between a number of incomegenerating ventures owned by a market trader and savings account ownership. Thus, the probit results revealed that the probability of owning savings account increases by 0.023 with one additional increase in a number of income generating ventures owned by a market trader, all things being equal. This finding is strongly underpinned by the fact that the motivation to engage in multiple business ventures is to augment income mobilization prospects of the market trader. Thus, any additional income generated from multiple 
engagements in business makes the market trader highly inclined to set aside some financial resources for savings purposes. This finding supports that of Ijaiya et al. (2009), That income source diversification through multiple income generating ventures offers an opportunity to enhance one's financial investment desire. Finally, the study's results show a positive and statistically significant relationship between financial education and savings account ownership. The results show that at one percent significance level, financial education increases the probability of owning savings account by 0.113 . This means that if an individual market trader receives financial education from financial institutions, the likelihood of taking the decision to own savings account increases; all things being equal. This finding is plausible; it is often argued that financial education improves one's financial knowledge, which serves as a conduit for a thorough understanding of financial products.

Regression Diagnostics and Post Estimation Tests: It is always imperative to ensure that regression estimates are robust, unbiased and consistent. Therefore, the following post-estimation tests were carried out after the analysis of the data. This can impact positively on financial planning and financial decision. This finding is in agreement with Amu and Amu (2012) who found that low level of knowledge about savings among household heads has stifled the efforts of many households to own savings accounts. This finding again has implication for financial service providers, particularly the quest to reach out to a significant number of individuals and households with limited financial literacy. This implies that financial institutions via financial service awareness creation can mitigate the impact of asymmetric information, which impedes financial service information flow.

Test for Goodness-of-Fit: To ensure whether the probit model used fits the distribution and nature of the available data well, the Hosmer-Lemeshow's goodness-of-fit test was carried out. With this, the extent to which the predicted frequencies and observed frequencies closely match must be ascertained. Thus, the closer the predicted event rates match the observed event rates, the better the fit. With the null hypothesis stated as "the model is fit", the probability value $(P-$ Value $)$ which matches the computed Pearson chisquare statistics must not be significant. Thus, the $P-$ Value $=0.2113$ shown in Table 2 , we fail to reject the null hypothesis and therefore, the model fits the data hence, reliable.

Model Specification Error Test: The probit regression model is built on the assumption that all relevant variables are included on the right-hand side of the equation, and that the model does not incorporate variables that should not be in it. The link test was conducted for the probit model used in this study. The test produces the associated $P$-values of the linear predicted value and the linear predicted value squared. In the case of testing for omitted variable, emphasis is placed on the linear predicted value squared (_hat Squared) and it is not supposed to be significant. As far as this study is concerned, the probit model passed the omitted variable test as presented in Table 2. Given the $P$-Values of the square of explained sum of square (_hat Square) to be 0.553 , we fail to reject the null hypothesis, thus, the model is correctly specified.

\section{Conclusion and Recommendations}

The study empirically sought to examine factors that determine savings account ownership status specifically among market traders from selected major market centres in Ghana. Probit regression analysis was used to examine data from the market traders. From the results and discussion thus far, gender (female dummy) is a significant determinant of savings account ownership but decreases the likelihood that individual market trader will own savings account. Specifically, a female market operator is less likely to own a savings account than a male counterpart. Categories of marital status such as single, married and divorced are significant but reduce the likelihood that a single, married and divorced market trader will own savings account compared to a widow. As hypothesized, a number of dependents have a significant influential role in predicting savings account ownership status, but the number of dependents reduces the probability of savings account ownership by a market trader. Thus, a market trader having dependents under his or her care will have less inclination to save. Also, on the relationship between savings account ownership and number of income generating vestures owned.

The results indicate a positive and significant relationship between savings account ownership and number of incomes generating ventures owned by a market trader. Thus, an increase in the number of income- 
generating business ventures engaged in increases the probability of owning savings accounts among market traders. On the effect of financial education on savings account ownership, the study shows that financial education impact positively on savings account ownership decisions and thus, increases the probability that a market trader will own savings account. Based on the conclusions from this study, the following recommendations are offered. Firstly, banks and financial institutions should intensify financial education strategies to boost savings mobilizations. Secondly, there should be an empowerment of females in the market business via government's policy intervention directed towards informal sector enterprise development to the crowd in revenue to improve their savings. Thirdly, National Board for Small-Scale Businesses in Ghana should intensify education on how to sustain diverse income generation ventures to fetch income from multiple sources to inspire behavioral intentions to save.

\section{References}

Abdul Mumin, Y., Razak, A. \& Domanban, P. B. (2013). Analysis of household heads' decision-to-save with financial institutions in Ghana. Asian Economic and Financial Review, 3(11), 1466-1478.

Abebe, G., Biruk, T. \& Yukichi, M. (2018). Changing saving and investment behaviour: The impact of financial literacy training and reminders on micro-businesses. Journal of African Economies, 134-142.

Acheampong, I. K. \& Wiafe, E. A. (2013). The link between poverty and social exclusion in Ghana: An Econometric Approach. Journal of Arts and Social Sciences, 1(2), 103-120.

Ackah, C. \& Asiamah, P. J. (2014). Financial regulation in Ghana: Balancing inclusive growth with financial stability.

Addai, B., Adjei G. G. \& Boadi, K. O. (2017). Savings habit among individuals in the informal sector: A case study of Agbegeyishie fishing community in Ghana. International Journal of Economics and Finance, 9 (10), 262-272.

Afoakwah, C., Annim, S. K. \& Peprah, J. A. (2015). Household savings and women bargaining power in Ghana. Journal of Global Economics, 3(2), 1-7.

Amu, M. K. \& Amu, E. K. (2012). Saving behaviour in rural Ghana: A study of rural households in the Ho Municipality of the Volta Region. Online Journal of Social Sciences Research, 1(2), 54-61.

Ando, A. \& Modigliani, F. (1963). The life-cycle hypothesis of saving: Aggregate implications and test. American Economic Review, 88(4), 55-84.

Arent, S. (2012). Expectations and savings behaviour: An empirical analysis, (Ifo Working Paper No. 128). Leibniz Institute for Economic Research. Munich, Germany.

Basu, A., Blavy, R. \& Yulek, M. (2004). Microfinance in Africa: Experience and lessons from selected African countries (IMF Working Paper No. 174). Washington, D. C: International Monetary Fund.

Chen, M. A. \& Dunn, E. (1996). Household economic portfolios: Assessing the impact of microenterprise services (AIMS). Retrieved from https://waleolusi.files.wordpress.com.

Dupas, P. \& Robinson, J. (2013). Saving constraints and micro-enterprise development: Evidence from a field experiment in Kenya. American Economic Journal: Applied Economics, 5(1), 163-192.

Dziwornu, R. K. \& Anagba, K. K. (2014). Understanding the factors that influence saving decision among small business owners in the Greater Accra Region of Ghana. European Journal of Business and Management, 6(32), 113-120.

Friedman, M. (1957). A theory of the consumption function. Princeton: Princeton University Press.

Goldberg, J. (2014). Products and policies to promote saving in developing countries. IZA World of Labour.

Gravelle, H. \& Rees, G. (2004). Microeconomics (3rd Ed.). England: Pearson Education.

Ijaiya, M. A., Ijaiya, G. T., Bello, R. A., Muftau, A. I. \& Ijaiya, M. A. (2009). Income diversification and household Wellbeing Ilorin Metropolis, Nigeria. International Journal of Management, Economics and Information Technology, 1(1), 12-22.

Incoom, S. E. (2009). The monetary and financial system (2nd Ed.). Accra, Ghana: Chartered Institute of Bankers (Gh).

Karlan, D. \& Zinman, J. (2018). Price and control elasticities of demand for savings. Journal of Development Economics, 130, 145-159.

Karlan, D., Ratan, A. L. \& Zinman, J. (2014). Savings by and for the Poor: A research review and agenda. Review of Income and Wealth, 6(1), 36-78.

Keynes, J. M. (1936). The general theory of employment, interest and money. London: Macmillan Publishing Co. Inc. 


\section{Journal of Social and Development Sciences (ISSN 2221-1152)}

Vol. 10, No. 1, pp. 52-61, March 2019

Modigliani, F. (1986). Life cycle, individual thrift, and the wealth of nation. American Economic, 76(3), 297313.

Musah, S. A., Bagah, D. A. \& Wulifan, J. K. (2015). The contribution of small and medium scale enterprises to economic growth: A cross-sectional study of Zibilla in the Bawku West District of Northern Ghana. European Journal of Business and Management, 7, 40-56.

Olson, D. H. \& DeFrain, J. ( 2000). Marriage and the Family: Diversity and Strength (3rd Ed.). London: Mayfield Publishing.

Osei-Assibey, E. (2013). Source of finance and small enterprise's productivity growth in Ghana. African Journal of Economic and Management Studies, 4(3), 372-386.

Owusu-Bempah, G., Bennet, E., Amoako, D. \& Frimpong, K. R. (2013). The importance of the informal sector to savings and loan companies. Research Journal of Finance and Accounting, 4(2), 108-116.

Rehman, H., Faridi, M. Z. \& Bashir, F. (2012). Household saving behaviour in Pakistan: A case of Multan District. Pakistan Journal of Social Sciences, 30(1), 17-29.

Schaner, S. (2016). The persistent power of behaviourial change: Long-run impacts of temporary savings subsidies for the poor (NBER Working Paper Series No. 22534). National Bureau of Economic Research. Cambridge, United Kingdom.

Tandoh, I. \& Tando, V. (2015). Dynamics of saving culture in Ghana. South American Journal of Management, $1(2), 1-13$.

Todaro, M. P. \& Smith, S. C. (2009). Economic Development (10 th Ed.). London: Perason.

United Nation Development Proramme. (2007). Human development indicators report Ghana; towards a more inclusive society. UNDP Ghana, Combert Impression.

Vosen, M. (2012). A fixed amount saving and the permanent income hypothesis (Ruhr Economic Papers No. 363). Dortmund, Germany: Ruhr-Universitat Buchum (RUB), Department of Economics.

World, Bank. (2008). Finance for all? Policies pitfalls in expanding access. A policy research report. Washington D.C: The World Bank.

Yee-Kwong, C. (1996). Banking services for young intellectuals. International Journal of Banking Marketing, 11(5), 33-40.

Zeller, M. (1999). The role of micro-finance for income and consumption smoothing. Paper presented at InterAmerican Development Bank's Conference on social protection and poverty, Washington D.C, February 5th, 1999. 